\title{
Emotional Intelligence as a Determinant Factor of Successful Leadership
}

\author{
Timea BODA \\ Adjunct Professor \\ College of Szolnok, Szolnok, Hungary
}

\begin{abstract}
Emotional intelligence is a summary of abilities that determine the success of a leader, how effective he will be in business life. A leader should make himself conscious of emotional abilities such as motivation, proactivity, flexibility, commitment, trust and others in order to establish an intelligent, well-functioning organisation with satisfied employees, to establish a company that is capable of rapid adjustment to changes.
\end{abstract}

Keywords: emotional intelligence, competencies, motivation, proactive leader, managerial efficiency

Abreviations: EI: emotional intelligence, EQ: emotional quotient

\section{INTRODUCTION}

The role of knowledge as a key factor of company competitiveness is getting more and more attention. "Knowledge economy", the availability of knowledge is the key factor to success - if knowledge does not stay in the possession of the employees but if it is shared and applied in a way that leads to increased value-added. Sharing knowledge is based on a number of abilities that are related to emotional intelligence. It is important for the worker to be motivated, to be able to cooperate with others and for him to trust in his environment, in his managers and in his organisation. The emotionallyintelligent leader, who finds the right person for the right job and supports the person induces constant development opportunities and creates an emotionally intelligent organisation.

It is worthwhile thus to examine what the factors that influence the success of a leader and his organisation. In the 1990s a complex research has been completed that researched the factors that determine a child's efficiencyand success in later adulthood. The outcomes show that even in the case of eminent children school performance determined the later business persons' and managers' performance only by $18 \%$. Even more important, the emotional quotient, emotional intelligence and internal mental abilities accounted for the remaining $82 \%$. Such abilities are the abilities to build relationships, empathy, self-awareness, self-discipline and motivation. These are abilities that determine our private and professional life.

Trust and cooperation within an organisation, attitude towards clients, co-workers and to working itself, willingness to change are all factors that determine success and that strongly root from human emotions. Therefore the ability to handle emotions is often the most important skill in an organisation for the leader. It is essential to train future business persons and leaders in these competency areas. In my article I wish to point at the emotional competencies that support professional performance. I give an overview of the theoretical background of emotional intelligence and then I analyse the successful leader's most essential emotional abilities.

\section{OVERVIEW OF EMOTIONAL INTELLIGENCE THEORIES}

\subsection{Definition of Emotional Intelligence}

Though the official definition of emotional intelligence dates back to 1990, Thorndike in 1920 has introduced the expression social intelligence that he has separated from abstract and practical intelligence much earlier. He considered that these abilities influence the success of our social relations and help us to understand and interpret other peoples' behaviour. The term was later frequently used. All authors of these publications emphasized theoutstanding role of emotions [1]. 
Later, Salovey and Mayer in 1990used the expression social intelligence to developtheir own theory.The term "emotional intelligence" was first used in an article of a German author, in which the psychoanalysis professor stated that the early separation of women from their mothers results in underdeveloped emotional intelligence [2].

Gardner (1983) made the first attempt to give an exact definition and to develop a theory by developing his theory of multiple intelligences. In his theory he also defined the terms intrapersonal and interpersonal intelligence. He suggested that intrapersonal intelligence helps us to understand our emotions and our behaviour while interpersonal intelligence helps us to understand others better.

1990 was a milestone in the development of emotional intelligence theories; two crucial theories were born. Salovey and Mayer (1990) introduced their theory on emotional intelligence and Saarni (1990) published his emotional intelligence model, in which he drew up eight closely-related socialemotional competencies:

1. Awareness of one's own emotions,

2. Ability to discern and understand other's emotions,

3. Ability to use the vocabulary of emotion and expression,

4. Capacity for empathic involvement,

5. Ability to differentiate subjective emotional experience from external emotion expression,

6. Adaptive coping with aversive emotions and distressing circumstances,

7. Awareness of emotional communication within relationships, and

8. Capacity for emotional self-efficacy

The real break-through in the research of emotional intelligence was Goleman's bestseller published in 1995 (Goleman 1995). The role of Goleman is significant in emphasising the significance of emotional intelligence, but his researches were criticized because of the lack of empirical evidence.

A number of research papers on emotional intelligence have been published at the turn of the millennium. Most of the researches have examined the role of emotional intelligence in job performance andfocused on definition and measurement. To facilitate the transparency of models the newly emerging models were categorised into systems.

The next sub-chapter gives an overview of the major four models of emotional intelligence that determine the researches of the area.

\subsection{The Most Well-Known Theories of Emotional Intelligence}

\subsubsection{The Goleman model}

The innovationof Golemanin the theory of emotional intelligence was that he has highlighted the role of emotional intelligence in job performance. Later he has extended this relation to group and organisational performance (Cherniss 2001, Cherniss-Goleman 2003, Goleman 1998b, Goleman 2001a). Goleman highlighted the relation between emotional intelligence and efficiency and wealth (Boyatzis et al, 2000, Goleman 1995). The major practical use of his theory lies is clarifying that thedifference between average performance and outstanding performance of a worker is great - the difference can determine the success and effectiveness of both a leader's and a company' performance. To capability to measure may be essential in recruitment and selection.

In 1998 Goleman has reduced the factors of his emotional intelligence model to four: self-awareness, self-management, social competence and relationship management. Efficiency and success are in the focus of the definition. According to Goleman emotional competence is a learnt competence that is based on emotional intelligence and contributes to outstanding job performance [3].

Table 1 (Goleman-Boyatzis-McKee 2002, 2003) summarizes the nineteen competencies that characterize the four clusters of the Goleman model. 
Table1. The structure of emotional suitabilities

(Goleman-Boyatzis-McKee 2002, 2003.) [4]

\begin{tabular}{|c|c|c|}
\hline & Personal & Social \\
\hline & & ncies \\
\hline & Self-awareness cluster & Social Awareness Cluster \\
\hline Awareness & $\begin{array}{ll}\text { - } & \text { Emotional self-awareness } \\
\text { - } & \text { Accurate self-assessment } \\
\text { - } & \text { Self-confidence } \\
\end{array}$ & $\begin{array}{ll}\text { - } & \text { Empathy } \\
\text { - } & \text { Service orientation } \\
\text { - } & \text { Organizational awareness } \\
\end{array}$ \\
\hline & Self-management cluster & Relationship Management Cluster \\
\hline Management & $\begin{array}{ll}\text { - } & \text { Adaptability } \\
\text { - } & \text { Emotional Self-Control } \\
\text { - } & \text { Initiative } \\
\text { - } & \text { Achievement orientation } \\
\text { - } & \text { Trustworthiness } \\
\text { - } & \text { Optimism } \\
\end{array}$ & $\begin{array}{ll}\text { - } & \text { Inspirational Leadership } \\
\text { - } & \text { Developing Others } \\
\text { - } & \text { Change catalyst } \\
\text { - } & \text { Conflict management } \\
\text { - } & \text { Influence } \\
\text { - } & \text { Teamwork and Collaboration }\end{array}$ \\
\hline
\end{tabular}

Competence researches revealed that those people performed best in certain jobs that possessed five or six of the competencies at a higher level and those, who had at least one competence out of each cluster.

\subsubsection{The Cooper and Sawaf model}

Cooper and Sawaf (1998) interpret the definition of emotional intelligence in a more complex way than the previous models. According to Cooper and Sawaf emotional intelligence is an ability that helps the individual to sense, understand and effectively apply the power and acumen of emotions as a source of human energy, information, connection and influence[5].

Cooper and Swarf have built their emotional intelligence model on the following four cornerstones:

Table2. The four cornerstones of emotional intelligence

(Cooper and Sawaf 1998)

\begin{tabular}{|c|c|c|c|}
\hline $\begin{array}{c}\text { First cornerstone } \\
\text { Emotional literacy }\end{array}$ & $\begin{array}{c}\text { Second cornerstone } \\
\text { Emotional fitness }\end{array}$ & $\begin{array}{c}\text { Third cornerstone } \\
\text { Emotional depth }\end{array}$ & $\begin{array}{c}\text { Fourth cornerstone } \\
\text { Emotional alchemy }\end{array}$ \\
\hline Emotional honesty & Authentic presence & $\begin{array}{c}\text { Unique potential and } \\
\text { purpose }\end{array}$ & Intuitive flow \\
\hline Emotional energy & Trust radius & $\begin{array}{c}\text { Commitment, } \\
\text { accountability and } \\
\text { conscience }\end{array}$ & Reflecting time-shifting \\
\hline Emotional feedback & Constructive discontent & Applied integrity & Creating the future \\
\hline Practical intuition & Resilience and renewal & $\begin{array}{c}\text { Influence without } \\
\text { authority }\end{array}$ & Opportunity sensing \\
\hline
\end{tabular}

Besides enumerating abilities and competencies the theory specifies qualities under which the model approaches the definition of emotional intelligence based on human personality, relations and awareness. In this respect the theory goes beyond previous theories [6].

Cooper and Sawafadded two more elements to previous models: the role of time management and the significance of commitment in the field of work efficiency.

\subsubsection{The Higgs-Dulewicz model}

In their model Higgs and Dulewiczhave laid an emphasis on control and leadership. They suggest that emotional intelligence is the ability with which we can manage our own emotions, as well as recognise and deal with other people1s emotions and behaviour. In their model motivation, instinct and ethical behaviour also have a large role.

In their model they identified the following three components of emotional intelligence [7]:

1. Drivers: motivation and decisiveness (energising and driving towards goal achievement)

2. Constrainers: conscientiousness and integrity (the fit between principles, values and behaviour)

3. Enablers:sensitivity, influence and self-awareness(performance traits which contribute to success) 


\subsubsection{The Bar-On model}

The Bar-On model of emotional intelligence describes emotional-social intelligence as a row of interrelated emotional and social competencies, skills and behaviours that impact intelligent behaviour. The model can be divided into two fundamental parts. The first part is the theory itself; the second part is the psychometric aspect of this model which is about measuring emotional-social intelligence.

According to Bar-On, emotional intelligence is an arry of knowledge and abilities that determine how a person can cope with the effects of the environment. He has classified them into five groups:

Table3. Components of the Bar-On Emotional Intelligence model

(2006)

\begin{tabular}{|c|c|c|c|c|}
\hline \multicolumn{5}{|c|}{ Emotional intelligence } \\
\hline $\begin{array}{c}\text { General } \\
\text { Mood }\end{array}$ & Adaptability & $\begin{array}{c}\text { Stress } \\
\text { management }\end{array}$ & Interpersonal & Intrapersonal \\
\hline Optimism & Reality-testing & Stress & Empathy & Self-Regard \\
Happiness & Flexibility & Tolerance & Social & Emotional Self Awareness \\
& Problem-Solving & Impulse Control & Responsibility & Assertiveness \\
& & & Interpersonal & Independence \\
& & & Relationship & Self-Actualisation \\
\hline
\end{tabular}

According to the model, to what extent we possess these factors determine how effective we are in our job and in our private life. Even more, in case of an entrepreneur and a manager, the possession of the factors also has a big effect on the efficiency of the organisation and its employees.

If a leader possesses high-level intrapersonal abilities, he is confident, irrespective, isable to express his feelings and to communicate his opinion. All these are essential e.g. to business plan development, in which definite and concrete aims have to be expressed and explained.

Leaders with highly-developed interpersonal abilities work well in a team, they have trust in other people and themselves, and they are responsible and reliable. These abilities may form the basis of the development and maintenance of an entrepreneur's business relations, relationship network long-term trust-based business co-operation.

Leaders with good stress-management abilities manage to perform well even under pressure because they can control their feelings and can work calmly. They react adequately in cases of emergency and can even think pro-actively in times of economic crisis.

Leaders with good adaptability abilitiescan interpret reality and solve problems adequately. In the life of an entrepreneur the business environment is constantly changing and that requires continuous adaption. It is important for an entrepreneur to be flexible to changes, even to forecast events and be pro-active before the event happens.

Leaders whose general mood is positive are more satisfied with their lives and their achievements than others. Their optimism may be of great value for the company to help perceive positive prospects. They feel larger self-motivation in achieving their plans and they are able to motivate people they work together with. All this can determine the effectiveness and the vision of a team.

All of the four models bring new areas of emotional competencies, but there are numerous factors that are to be found in all four of them. Common factors are e.g. accurate self-assessment, emotional selfefficacy, self-realization, emotional awareness and control and flexibility.

\section{THE IMPACT OF EMOTIONAL INTELLIGENCE ON THE SUCCESSFULNESS OF A LEADER}

Leadership suitability depends only partly on IQ. An effective accomplishment of managerial tasks depends on the communication and negotiation skills of the leader, how he can apply the acquired knowledge, whether he is able to motivate others to help him reach his aims. Can he develop his business strategy in a way that it ensures sustainability and growth? The emotionally intelligent leader possesses high-level empathy, recognizes his co-workers'working style and is able to find the right person for the right job. The emotionally intelligent leader creates confidence and thereby reduces fluctuation to a minimum level, he builds communities. 
In today's uncertain economic environmentsuch abilities are highly appreciated because it is in the interest of managers and companies to achieve as much as possible with the lowest possible investment to be able to react fast tothe challenges of the changing environment. Many large companies have realised the significance of emotional intelligence in the area of efficiency, thus have embodied elements in their recruitment and selection systems that make measures on their future employees.

A research made by L'Oréal verified this. According tothe research, sales persons, who were selected by certain emotional competencies managed to sell more than the ones who were hired using the old recruitment and selection methods (Spencer \& Spencer, 1993; Spencer, McClelland, \& Kelner, 1997). Emotional intelligence research at the US Air Force showed that recruitment officers who were chosen with the help of an EQ test managed to recruit three times many people than ones who were chosen differently (Cherniss 1999). A research made by the research agency Egon Zehder International has involved 515 top managers in their analysis. Managers, whose emotional intelligence was high, were much more successful than the ones that had larger experience or a higher IQ. 74\% of successful managers had a high emotional intelligence, as for in the case of less successful ones this value was only $24 \%$ [9].

Chernis (1999) has summarised the results of numerous research projects and came to the conclusion that abilities related to emotional intelligence determine job performance, efficiency and managerial success. In one of the research projects employees of 200 companies were tested and the researchers came tothe conclusion that one third of them were successfulbecause of their experience and their cognitive skills, but the other two third's success relied on the employees' emotional competencies. In the case of top managers more than four fifth of them were successful because of their emotional intelligence [10].

Ternovszky suggests that successful leaders possess emotional intelligence that is "the ability to develop one'sself and one's human relations". The leader should be aware of his qualities, his strengths and weaknesses should be able to control his feelings, make relations and to sustain and develop them [11]. "Thus the real profit potential lies in the human factor"[12].

Goleman suggests that the competencies that influence a leader's effectiveness can be identified. He highlights that emotional competencies, emotional-physic factors not only influence the performance of managers but also the performance of subordinate co-workers. This improves the effectiveness of the organisation. According to Goleman, emotional competence is a learnt skill that is based on emotional intelligence and that leads to outstanding job performance [13].

Golemaneemphasises that the emotionally intelligent management radiates a power that incites and inspirits employees, and that manages to keep up a level of commitment. He also proved that successful managers possess higher-than-average emotional intelligence[14].

He states that the difference between average and excellent leader is emotional intelligence. Leaders with a higher EQ manage to create resonance easier; that is they can create a positive atmosphere, and as a result they can increase the performance and creativity of their employees.

Evidence is provided by the research outcomes of the Hidden Brain Drain Task Force. The researchers found that in 2007-2008 in companies in crisis on Wall Street loyalty and commitment dropped. Loyalty dropped from $95 \%$ to $39 \%$, commitment from $91 \%$ to $65 \%$ [15].

In such a crisis situation it is particularly important to clarify again and again why members joined the organisation and thereby maintaining their bondage and motivation. This is important to be able to keep the very talented employees who possess valuable competencies. Fluctuation is very unfavourable for an organisation because fluctuation generates extra costs; it takes a lot of time and work to train a new worker. It is the job of the emotionally intelligent leader to find the best methods with which he can maintain the level of commitment and - with new assignments and aims - can give new impetus to the organisation and its members. Below you can find the emotional intelligence abilities that most researchers agree on a successful leader should have.

According to Boyatzis it depends mainly from the aptitude of the managers how much profits human capital, human resources produce for a firm. He states that companies need capable leaders to achieve their goals effectively [16]. 
A leader may not lose his enthusiasm and positive attitude in times of crisis. Also Bar-On emphasised in his model the significance of general mood. This idea was supported by the research at Met Life where researchers found that new sales people who reached high points in the test on learnt optimism sold $37 \%$ more life insurances in their first two years than the pessimists [17].

Optimism, thus, as an emotional competence has led to the increase of effectiveness. It is also important for a leader to realize the favourable opportunities emphasized by Cooper and Sawaf; not only the financial and investment opportunities but also in people the competencies that are necessary for creative work and effective team-building.

Leading a company is real teamwork. Team work requires many abilities that assume a certain level of emotional intelligence. To be able to cooperate members of a group must learn to show selfrestraint, to convince others, to be considerate and understanding. This is confirmed by the research paper of Druskat and Wolf(2002) on the efficiency of the group. They state that there are three factors determine on what level a group solves a problem. These factors can be relatedto emotions: trust, team spirit and the supportof the community [18].

According to Ferenc Mérei, a psychologist decentralisation is closely related to emotional intelligence. Decentralisation in this sense means that the leader - with the help of his empathy - feels and understands what another person experiences. What does he think the truth is? I do not put myself in the centre of the world but try to interpret happenings from the point of view of my environment.

Tamás Vekerdy, apsychologist emphasises in many of his books the role of emotional intelligence in the success in life. He summarises the meaning of EI in the following way: "Well, emotional intelligence is what pervades and moves our sociability, our conformation to the community, our suitability verification while it relies on emotional safety. Children receive this emotional safety primarily in the family. No doubt, later institutions have a great role in the further development of EQ, or, as many people experience, in ruining and restricting it." [19].

There are no limits to the development of emotional intelligence. Based on stimulus from childhood and on observations it seems to be a fact that mainly experience in art activities determinesa child's, later adult's level of emotional intelligence. Emotional intelligence can later be further-developed. It is extremely important to integrate trainings, exercises and art activitiesinto activities in kindergarten, primary, secondary and higher education because they develop children's and young adults' emotional intelligence. Many alternative education methodologies have realized the significance of this and like the Waldorf method and develop visualisation, creativity, thinking in the community with the help of arts. It is essential to complete parenting with a supportive education environment. It is worth to develop our EQ; that can make us a better and happier person in our private and professional life.

\section{SUMMARY}

Today a company's sense of security should not rely on traditions and time-honoured methods but on the summary of competencies that prepare a company, its managers and employees to always be able to develop in a given situation. To accomplish this it is necessary for the leader to have accurate selfevaluation, to realize his own and his company's strengths and weaknesses. It is essential for him to be able to shape his social relations to serve his personal development. Competencies that help among others - innovative thinking, change tolerance and initiative are getting more and more important. Emotionally intelligent leaders and organisations are needed who are able to act proactively in today's changing business environment. It is therefore essential that young entrepreneurs receive the help they need for later success as early as possible. Availability of multiple opportunities that develop emotional intelligence and ones that take into account the special needs of various age groups and develop them adequately is an essential need.

\section{REFERENCES}

[1] HendlugJ.and Sternberg RJ 2000.: Túl sok intelligencia? Integráló társadalmi, érzelmi, és gyakorlati intelligencia, fejlesztését, vizsgálatát, és az alkalmazás otthon, az iskolában, ésa munkahelyen, San Francisco, CA: Jossey-Bass Inc, 2000.

[2] Leuner, 1966 cited in Zeidner et al,What We Know About Emotional Intelligence - How It Affects Learning, Work, Relationships, and Our Mental Health, A Bradford Book, The MIT Press, Cambridge, Massachusetts, London, England, 2009 
[3] Balázs L., Érzelmi intelligencia a szervezetben és a képzésben Z-Press Kiadó Kft. Miskolc, 2014

[4] Balázs L., Érzelmi intelligencia a szervezetben és a képzésben Z-Press Kiadó Kft. Miskolc, 2014

[5] Balázs L., Érzelmi intelligencia a szervezetben és a képzésben Z-Press Kiadó Kft. Miskolc, 2014

[6] Mayer J. D., Salovey P., Caruso, D.R., Emotional intelligence as zeitgeist, as personality, and as mental ability. In: Bar-On R. - Parker J.D A. (Ed.) The handbook of emotional intelligence: Theory, development, assessment, and application at home, school, and in the workplace. JosseyBass, San Francisco, 2000

[7] Balázs L., Érzelmiintelligencia a szervezetbenés a képzésben Z-Press KiadóKft. Miskolc, 2014

[8] Balázs L., Érzelmiintelligencia a szervezetbenés a képzésben Z-Press KiadóKft. Miskolc, 2014

[9] ChernissC., The Business Case for Emotional Intelligence. Prepared for the Consortium for Research on Emotional Intelligence in Organizations, 1999, http://doreenmcgunagle.com/files/ EI_Case_Study.pdf, accessed: 05022015

[10] SpencerL., The Economic Value of Emotional Intelligence Competencies and EIC-Based HR Programs. In The Emotionally Intelligent Workplace, 1997

[11] Ternovszky, F., Nemzetközimenedzsmenteurópaiszemmel. SzókratészKiadó, Budapest, 2003

[12] Fábián,E., Mitérhetazelkötelezettmunkatárs? Magyar Grafika, Expo special edition, 2007/5

[13] Goleman,Daniel, Working with Emotional Intelligence, Bantam Dell, New York, 1998

[14] Goleman, D., Boyatzis, R., McKEE, A természetesvezető. Azérzelmiintelligenciahatalma. Budapest, Vince Kiadó, 2003

[15] Sylvia A. H.,Csúcstehetségek AKADÉMIAI KIADÓ, 2011

[16] Boyatzis R., The competent manager Wiley, New York, 1982

[17] Seligman M, Learned Optimism: How to Change Your Mind and Your Life, New York, NY, Pocket Books, 1990

[18] KovácsT., A bizalomszerepeéshelyeazérzelmiintelligenciában. PeriodicaOeconomica, 2010

[19] Vekerdi T, Nagy Családkönyv, Central MédiacsoportZrt., 2015 